\title{
PLANT PROTECTION: TRADE AND THE ENVIRONMENT
}

\author{
D. PIMENTEL
}

\author{
College of Agriculture and Life Sciences, 5126 Comstock Hall, \\ Cornell University, Ithaca, New York 14853-0901, U.S.A.
}

\begin{abstract}
Plant protection, trade, and a quality environment have complex interrelationships. Despite the annual application of 2.5 million tons of pesticides in the world, pests destroy more than $40 \%$ of total potential food production. This represents an enormous loss of food for either consumption or export at a time when more than two billion humans are malnourished in the world. Although worldwide pesticides reduce some losses inflicted by pests, they also cause serious public health and environmental pollution problems which cost about $\$ 100$ billion per year. Keywords: Plant protection trade environment pesticides
\end{abstract}

\section{INTRODUCTION}

Plant protection involves preventing and/or limiting the pest attacks on crop plants and livestock. In order to insure adequate food production, pest species have to be controlled whether they are native or introduced exotic.

World trade, which now totals more than $\$ 7,000$ billion each year (USBC 1996), is projected to continue to expand in future decades. At present, New Zealand's food exports total more than $\$ 20$ billion/year (NZ 1993) compared with U.S. food exports of more than $\$ 40$ billion/year (USBC 1996). Food exports not only augment the food supplies of importer nations but also support agricultural production and help domestic industries and trade balances of the exporter nations. Unfortunately trade facilitates the importation of new plant and animal pests which can become serious economic problems.

In the 1950s most nations were fairly self sufficient in food, and nearly half of these nations were net exporters of food. However, today only seven out of a total of 183 nations are net food exporters; New Zealand and the United States are two of these (Giampietro and Pimentel 1993). This means that a majority of nations depend on food imports to improve the food supplies of their citizens.

Insuring adequate food supplies becomes ever more vital as the world population continues to rise. Already more than two billion people in the world are now malnourished (WHO 1995). This is the largest number ever recorded in history. Compounding the problem is the fact that per capita grain production in the world has been declining for the past 15 years (FAO 1996; Pimentel et al. 1997a). Grains as a group make up 80\% of the food consumed worldwide.

While the per capita world food supply has been declining, serious environmental problems have been increasing due to the rapidly expanding world population and shortages of the basic resources required for food production (Pimentel et al. 1997a; 1997b). The expansion of world trade increases the potential for more pest problems, increased pesticide use, and greater concern about protecting the environment.

The objective of this analysis is to examine the existing interrelationships among plant protection, trade and maintaining a quality environment in New Zealand and elsewhere in the world.

\section{EXTENT OF FOOD CROP LOSSES TO PESTS}

When food and fiber crops are attacked by pests, not only are crops significantly diminished but the human food supply is also reduced. At a time in history when we are witnessing rapid growth in the world population, protecting food harvests has become

Proc. 50th N.Z. Plant Protection Conf. 1997: 20-27 
a priority for all nations.

Approximately 70,000 species of pests exist in the world, but only $10 \%$ of these are considered serious pests (Pimentel 1997). Despite the use of more than 2.5 million tons of pesticides that are applied annually at a cost $\$ 30$ billion, pest insects, plant pathogens and weeds continue to destroy more than $40 \%$ of the potential world food production (Oerek et al. 1994; Pimentel 1997). Preharvest pest losses are approximately $15 \%$ for pest insects, $13 \%$ for disease, and about $12 \%$ for weeds. After harvest, another $20 \%$ of the food is lost to another group of pests (Pimentel 1997).

In the United States, and probably in New Zealand, preharvest losses are slightly lower than the world average, at about 37\% (Pimentel 1997). The losses are allocated as follows: $13 \%$ from insects, $12 \%$ from diseases and $12 \%$ from weeds. These losses occur despite the heavy application of insecticides, fungicides and herbicides. Approximately $3 \mathrm{~kg}$ of pesticide are applied per hectare in the U.S. agricultural system (Pimentel et al. 1993) and this rate is considered to be similar to that of New Zealand.

\section{WIDESPREAD IMPACTS OF PESTICIDES}

Along with the many benefits that pesticides provide, their application frequently harms other plant and animal species in the ecosystem. Pesticides have been reported to poison livestock and contaminate milk, meat, and other livestock products (Pimentel and Greiner 1997). In addition, large numbers of honey and wild bees are poisoned by pesticides, thereby reducing their effectiveness as pollinators for fruits and vegetables. In the United States, the losses from bee kills and loss of pollination costs about $\$ 325$ million per year (Pimentel and Greiner 1997).

Sometimes unexpected pest problems emerge when herbicides are used on crop acreages (Pimentel 1995). For example, when the herbicide 2,4-D was applied at recommended dosages to corn, both insects and plant diseases increased (Pimentel 1995). Corn leaf-aphid populations were about three times more abundant on herbicide treated corn compared with the untreated corn. Corn borer populations were about $30 \%$ more abundant on the treated corn than on the untreated, and they grew $33 \%$ larger and produced $33 \%$ more eggs than on untreated corn. Not only did corn smut disease grow five times larger on the treated corn compared with the untreated corn, but the treated corn that normally was resistant to southern corn blight lost its resistance to the disease (Pimentel and Greiner 1997).

When applied pesticides destroy the natural enemies of pest species, increased pesticides must be applied to compensate for their loss. Not only do extra pesticides cost the farmer time and money, but more pesticides are released into the agricultural environment.

The impacts of pesticides are felt well beyond crop fields. Fish are killed in rivers and lakes and other wildlife is destroyed as well. For example, 67 million birds are killed by pesticides each year in the United States (Pimentel and Greiner 1997). Such losses not only diminish biodiversity but also adversely affect the public's ability to enjoy a healthy wild environment.

\section{PESTICIDES AND HUMAN HEALTH}

Since the advent of DDT for crop protection in 1945, the growth of pesticides throughout world agriculture has been phenomenal. In 1945, about 50 million $\mathrm{kg}$ of pesticides were applied annually worldwide (Pimentel 1997). To date there has been a 50 -fold increase in the use of pesticides; now approximately 2.5 billion kg of pesticides are applied worldwide annually (Pimentel 1995). Actually, the increase in pesticide use is greater than it appears because the toxicity and biological effectiveness of the newer pesticides have increased at least 10-fold during the past five decades (Pimentel 1995).

In 1945 when the new synthetics were first used, there were few reported pesticide poisonings. By 1973, after the significant increase in pesticide use (Pimentel 1995), the number of human pesticide poisonings reached an estimated 500,000 (with about 6,000 deaths) worldwide (Labonte 1989). Over the next 11 years, the number of pesticide poisonings increased three fold to 1.5 million (with about 22,500 deaths) worldwide (Labonte 1989). According to the World Health Organization, there are three million 
human pesticide poisonings annually in the world, of which approximately 220,000 each year are fatal and about 750,000 contribute to the development of chronic illnesses like cancer (WHO 1992).

Similarly in the United States, by the late 1960s the number of human pesticide poisonings began to increase rapidly, paralleling the increased use of pesticides, especially the highly toxic, low-dosage pesticides. For example, in California the use of pesticides increased from 68 million $\mathrm{kg}$ in 1950 to 269 million $\mathrm{kg}$ by 1988 , while the number of reported human poisonings rose from 115 in 1950 to 903 cases in 1988 (Maddy et al. 1990). By 1989, the total number of pesticide poisonings in the United States rose to 67,000 per year (Litovitzet al. 1990) and by 1996 reached 110,000 per year (Benbrook et al. 1996).

In the United States, the annual costs associated with public health problems and a broad range of other environmental problems, total more than $\$ 8$ billion (Pimentel and Greiner 1997). Worldwide the environmental costs for pesticide use have been estimated to be as high as $\$ 100$ billion per year (Pimentel 1997).

\section{CHARACTERISTICS OF EXOTIC AND NATIVE PEST SPECIES}

New Zealand has an estimated 50,000 species of plants, animals, and microbes (Halloy 1995). Unfortunately, only about one-third of these species have been described. For many reasons, including planning for adequate plant protection, it would be helpful if most of New Zealand's species were known.

There are an estimated 2,450 species of native plants present in New Zealand; however, approximately 6,000 species are introduced plants (Halloy 1995). At present 19 of the introduced plant species cover $95 \%$ of all cultivated land in New Zealand. Because introduced crop plants are exotic introductions, many native insect species moved from feeding on native vegetation to attacking the introduced crops. This has occurred in the United States and Europe where about $60 \%$ and $80 \%$, respectively, of the pest insects are native insects that eventually moved to feeding on the introduced exotic crops (Pimentel 1993). The remaining pest insects are introduced exotics.

The interaction between native and introduced plants is not unique to New Zealand. For example, Florida in the United States has only 2,525 indigenous plant species but approximately 25,000 plant species have been introduced and are under cultivation (Frank and McCoy 1995). There are an additional 925 species of exotic plants established in nature where some are displacing native plant species. One such exotic pest is the melaleuca (Melaleuca quinquenervia) tree introduced from Australia.

With the rapid growth in the world population and increased trade there has been an associated increase in exotic pests entering New Zealand and elsewhere in the world. Earlier it was mentioned that despite all the pesticides applied annually and all other controls, pests destroy more than $40 \%$ of all potential food production. Certainly part of the increased pest problem is the increase in exotic pests invading all nations.

The pest problem is just not exotic pests, as mentioned earlier. Thus, when a new crop plant is introduced into a country, it is an exotic plant introduced into a new association in a new biotic community. As expected, the introduced crops lack any resistance factors to protect them from the native herbivores because they had never coevolved (Pimentel 1961; 1988). Thus, a large number of native insect herbivores are able to increase their food resource by utilizing the susceptible introduced crop plants. In the real sense, these native organisms are "new pest invaders" of the exotic crop which was imported (Pimentel 1993).

In general, most crops are exotic plants introduced for cultivation. For example, in New Zealand and the United States corn was introduced from Central America, soybeans from China, wheat from the Middle East and potatoes from Boliva and Peru. In fact most grain, vegetable, and fruit crops can be considered exotic crops because they were imported. In contrast, most commercial forests are native species.

In addition to a crop being exotic, most crop habitats are unique in the sense that all native vegetation is destroyed before the crop is planted. Such an ecological situation provides a relatively simplified habitat inviting the invasion of introduced exotic pests as well as native pests that find the new crop to be a new food source. 
When the pests that invaded U.S. crops were examined, only $40 \%$ of insect species that are pests on U.S. crops were considered foreign-introduced pests (Pimentel 1993). Some of these exotic pests were brought along with the imported crops. Early in the 1600 s and 1700s, many were brought in with ship ballast that was often dumped on the land. Since most U.S. trade was with Europe, it is not surprising that most exotic insect pests in the United States came from Europe. Interestingly, Europe has fewer exotic pest insect invaders than the United States; only about $20 \%$ of their insect pests are exotic (Pimentel 1993).

The fact that most insect pests on crops are native species which moved on to introduced crops is typical throughout the world. For example, in most regions where sugarcane is introduced and established as a crop, a unique set of pest species becomes associated with it. Of 1,645 known pest species of sugarcane worldwide, "959 occur only in a single region and 156 in two regions. Only 18 pest species occur in more than 10 regions" (Strong et al. 1977). These data suggest that sugarcane pest groups develop primarily from native arthropods that have moved from local plants and not from arthropods introduced into the region from elsewhere. Nearly $60 \%$ of the arthropod pests of sugarcane are, in fact, native insect herbivores that have moved onto sugarcane in the habitat into which sugarcane was introduced. The percentage of native pests of sugarcane is similar to the percentage of native pests on U.S. crops.

An example of a native U.S. herbivore moving onto an introduced crop is the invasion of white potato by the so-called Colorado beetle. The potato originated in Boliva and Peru (Hawkes 1944). The Colorado potato beetle (Leptinotarsaisc decemlineata) is native to the United States and initially fed primarily on wild sanbur (Solanum rostratum) (Elton 1958). When the potato was introduced into the United States, it was exposed to the beetle. The introduced potato lacked any resistance to the potato beetle, enabling the beetle to become the most serious insect pest of potatoes here and later in many parts of the world, including Europe and Eurasia.

The invasion patterns of foreign plant pathogens in vegetable and grain crops in the United States are distinctly different from those of insect pests. Almost $40 \%$ of the 155 major plant pathogens associated with U.S. vegetables that were investigated had a worldwide distribution (Pimentel 1993). Often, the pathogenic microbes are brought in when a crop host is introduced into a new country or are brought in with the seeds of the crops themselves.

About $73 \%$ of the major U.S. weed species originally came from other countries (Pimentel 1993). Approximately $67 \%$ of the weed invaders came from Europe and Eurasia because of the long-term selection and the intensive early trade between the United States and those regions. Most probably the ballast from ships coming from Europe and Eurasia that was dumped on the North American continent was the carrier.

For several reasons, the pattern of the invasion of weeds in U.S. pastures is quite different from those associated with crops. Only $41 \%$ of the pasture weed invaders came from regions outside of the United States, whereas $73 \%$ of the weed invaders in crops were introduced species (Pimentel 1993). Similar to cultivated croplands, most (78\%) of the weed species in pastures came from Europe and Eurasia (Pimentel 1993).

Precisely how many weed species, plant pathogens and insect species have been introduced into the United States is unknown, but Sailer(1983) estimated that more than 1,500 insect species have been introduced and subsequently became established in the U.S. habitat. Most insect introductions appeared to have occurred after 1900 when trade and transportation significantly increased. The establishment of more than 1,500 species of insects confirms: (1) the relative ease with which insect species establish themselves in a new ecosystem; (2) the relatively small number of introduced species that were introduced and became pests (5\% to $10 \%$ ); and (3) that not all niches in nature for invasive species are filled.

\section{TRADE AND CROP PESTS}

From the foregoing discussion, it is obvious that pest problems will increase and the distribution of crop pests and their abundance will continue to widen as trade and travel expands among nations. Rapid growth in the number of people in the world is affecting all nations, their agriculture, and their pest problems. Considering the damage inflicted 
by all pests on food production, it is imperative that the introduction of exotic species be prevented. New Zealand is as vulnerable as the United States or any other nation.

The prime concern for the invasion of a new insect pest in New Zealand is the Mediterranean fruit fly (Ceratitis capitata) (MFF) (MAF 1996). This insect is easily introduced by travellers carrying fruits and vegetables in their luggage and not understanding the threat they pose to New Zealand's agriculture. Indeed, many different exotic insects and diseases pose a threat, especially to the fruit industry.

Consider that New Zealand exports approximately $\$ 800$ million per year of just kiwifruit and apples. Based on the value of these crops, Baker and Cowley (1989) concluded that it would be justifiable to invest $\$ 500,000$ to $\$ 1$ million to eradicate any introduced exotic pest that attacked these crops.

Unfortunately some new trade agreements between nations have the potential to increase the introduction of exotic pests into nations without certain pests. For example, Norway and other European countries agreed to a new trade agreement with the United States and Canada. Based on this agreement, all the involved nations are expected to drop several of their barriers for numerous import/export items, including food products. Thus Norway, for instance, is forced to import a certain quantity of apples from the United States at a certain time during each year (Professor T. Edland, Plant Protection Institute, As, Norway, 1996). At present, Norway does not have many of the apple pests that occur in the United States. Forcing the importation of apples into Norway is expected to increase the chances of introducing exotic apple pests into Norway. Professor Edland has already detected several U.S. apple pests on apples imported into Norway from the United States.

\section{PUBLIC CONCERN ABOUT PESTICIDES AND TRADE}

In developed nations like New Zealand and the United States, the public is becoming more concerned about the quantity of pesticides in foods and their distribution throughout the natural environment (Cullen 1993). In the United States for example, 97\% of the people surveyed indicated that they prefer to have food without pesticides (FDA 1989). Although $35 \%$ of U.S. foods have measurable pesticide residues, $1-3 \%$ have residues above the safe tolerance levels of contamination set by the FDA (1991). The expressed message is that consumers desire food without pesticides or with only minimal residues.

For exporter countries, whether they be developed or developing, the goal clearly is to minimize or eliminate pesticide residues on their exports. The presence of significant pesticide residues can often create a problem and can be highly costly. For example, while conducting research in Guatemala and attempting to reduce pesticide use in cotton, we observed a major problem with beef exports to the United States (ICAITI 1977). Two shiploads of beef to Miami, Florida had to be dumped because of the excessive levels of DDT and other pesticides found in the beef.

Following that costly rejection, Guatemala established a laboratory to test all beef for excessive pesticide residues prior to its being loaded aboard ship. Contaminated beef was not approved for export (ICAITI 1977). Unfortunately the rejected beef was then sold on the Guatemalan market (at a low price) and was consumed by the Guatemalan people.

Another example of contaminated beef being excluded from a market because of excessive pesticide residues occurred with the export of beef from Australia to Japan (Corrigan and Seneviratna 1989; 1990). Apparently the Australian Ministry of Agriculture permitted farmers in Western Australia to use DDT, dieldrin, and various other chlorinated insecticides in potato production for many years after these pesticides had been banned from use in most developed nations. Eventually cattle were permitted to graze on forage crops which had been planted on the pesticide contaminated land. As a result the beef became heavily contaminated and was unacceptable to the Japanese market. The Australian Minister of Agriculture, not the farmers, was to blame for permitting the continued use of chlorinated insecticides in agriculture when most other developed nations had banned them.

Furthermore, export problems are created when trade partners have quite different tolerances for pesticide residues, especially on fruits and vegetables. For example, raspberries exported from New Zealand face different carbaryl tolerances depending on 
the country importing the berries. A few carbaryl tolerances (ppm) for various countries are as follows: Belgium $=1.0 ;$ United Kingdom $=1.0 ;$ Sweden $=2.0 ;$ Australia $=10.0$; and United States $=12.0$ (Langford 1989). The exporter must find a way to meet these differing tolerance specifications.

Sometimes the presence of chemical residues are a barrier to the trade of some commodities (Burket and Grant 1990; Conklin and Thor 1995). In many countries where there is growing interest in global environmental problems, some may wish to use environmental regulations as barriers to trade (Nutrition Week 1991; Zilberman 1992). Although a recent report by the U.S. Government Accounting Office indicates that most pesticide residue tolerances are established to protect health and the environment, there is concern that some U.S. tolerances may hinder trade (Nutrition Week 1991). Whether the different levels of carbaryl tolerances for raspberries were established in part as trade barriers is not known, but this illustrates how tolerances might be used as trade barriers by some nations.

\section{ADVANTAGES OF CLEAN, GREEN FOOD FOR TRADE}

Because many citizens of New Zealand, the United States, and other developed nations favour foods without pesticides, foods produced without pesticides frequently receive a premium price in the marketplace (Christie 1993; Pimentel 1997). This situation is true whether the pesticide-free food is produced for the local market or the international market. The regulations for the importation of organically produced food into the United States and Europe have been reviewed by Centner (1995).

Pesticide-free food that is produced for consumption within New Zealand and the United States is sold at a premium both in domestic and export markets. Currently, in New Zealand about $0.2 \%$ of the total food produced is produced using organic agricultural technologies (Conacher and Conacher 1991), while the percentage of food produced organically in the United States and Europe is slightly higher, or about $1 \%$ (Conacher and Conacher 1991). In all regions there appears to be a rapidly growing market for organically grown fruits and vegetables (HealthFocus 1991). From one to three billion U.S. dollars worth of organic foods are sold in the United States (HealthFocus 1991). The consumer, however, must be aware of the different standards set for organic foods. There is a need for improved government regulations.

Although the great majority of the public in New Zealand and other nations prefer organically produced food (HealthFocus 1991), there is a serious and unexpected risk associated with importing organic food products. The risk is especially great with fruits, vegetables, and other such food products because they could be infested with exotic insects and plant pathogens. Because the probability for contamination is greater with untreated products than with the pesticide-treated fruits and vegetables, the possibility of introducing exotic pests is increased.

This far ranging discussion emphasizes the importance of developing policies that help achieve sustainable agricultural production and safe pest control strategies based on the minimal use of pesticides for the future.

\section{REFERENCES}

Baker, R. and Cowley, J., 1989. Evaluation of the economic impact of newly introduced pests. N.Z J. Forestry Sci. 19 (2/3): 330-334.

Benbrook, C.M., Groth, E., Hoaaloran, J.M., Hansen, M.K and S. Marquardt, 1996. Pest Management at the Crossroads. Yonkers, NY: Consumers Union.

Burket, S.D. and Grant, L.C., 1990. California Pesticide Residue Initiative: Probable Effects on U.S. International Trade in Agricultural Food Products. Washington, DC: U.S. International Trade Commission.

Centner, T.J., 1995. Organically-produced food products: regulations from the European Union and the United States set the stage for imports. J. International FoodProducts and Agribusiness Marketing 7 (4): 41-58.

Christie, R. 1993. Plant protection and international trade. Pp 1-10 In:Plant Protection: Costs. Benefits. and Trade Implications. D.M. Suckling and A.J. Popay (Eds). 
Lincoln, New Zealand: New Zealand Plant Protection Society Inc.

Conacher, J. and Conacher, A., 1991. An update on organic farming and the development of the organic industry in Australia. Biological Agric. Hort. 8: 1-16.

Conklin, N.C. and Thor, E.P., 1995. Pesticide regulation and inter-American trade. Agribusiness 11 (3): 281-289.

Corrigan, P.J. and P. Senevirantna. 1989. Pesticide residues in Australian meat. Veterinary Record J. Brit. Veterin.Assoc. 125 (8): 181-182.

Corrigan, P.J. and Senevirantna, P. 1990. Occurrence of organochlorine residues in Australia. Aust. Veterin. J. 67 (2): 56-58.

Cullen, R., 1993. Measuring the costs and benfits of plant protection. Pp 89-96In: Plant Protection: Costs Benefits. and Trade Implications. D.M. Suckling and A.J. Popay (Eds.). Lincoln, New Zealand: New Zealand Plant Protection Society Inc.

Elton, C.S., 1958 The Ecology of Invasions by Animals and Plants. London: Methuen.

FAO., 1996. FAO QuarterlY Bulletin of Statistics. Rome: Food and Agriculture Organization of the United Nations.

FDA., 1989. Food and Drug Administration Pesticide Program Residues in Foods-1988. Jour. Assoc. Off. Anal. Chem. 73: 127A-146A.

FDA., 1991. Residue Monitoring 1991. Washington, DC: Food and Drug Administration Pesticide Program.

Frank, J.H. and McCoy, E.D., 1995. Introduction to insect behavorial ecology: the good the bad and the beautiful: non-indigenous species in Florida.The Florida Entomol. $78(1): 1-15$.

Giampietro, M. and Pimentel, D., 1993. The Tightening Conflict: Population. Energy Use, and the Ecolog Y of Agriculture. Negative Population Forum, L Grant (Ed.). Teaneck, NJ: Negative Population Growth, Inc.

Halloy, R.P., 1995. Status of New Zealand biodiversity research and resources: how much do we know? J. Royal Soc. N.Z. 25 (1): 55-80.

Hawkes, J.G., 1944. Potato Collecting Expedition in Mexico and South America. Cambridge, England: Imperial Bureau of Plant Breeding and Genetics, School of Agriculture.

HealthFocus, 1991. New Product Opportunities in Organic Food. Washington, D.C.: HealthFocus and Marketing Intelligence Service.

ICAITI.,1977. An Environmental and Economic Study of the Consequences of Pesticide Use in Central American Cotton Production. Guatemala City, Guatemala: Central American Research Institute for Industry, United Nations Environment Programmme.

Labonte, R.N. 1989. Pesticides and healthy public policy. Can. J. Public Health 80: 238-244.

Langford, G.I. 1989. Progress toward pesticide free fruit in New Zealand: Rubus and Ribes. Acta Hort. 262: 193-199.

Litovitz, T.L., Schmitz, B.F. and Bailey, K.M., 1990. 1989 Annual Report of the American Association of Poison Control Centers National Data Collection System. Am. J. Emergency Med. 8: 394-442

Maddy, K.T., Edminston, S. and Richmond, D., 1990. Illness, injuries, and deaths from pesticide exposure in Califomia, 1949-1988. Rev. Environ. Contamin.. and Toxicology 114: 57-123.

MAF, 1996. Policy Issues and Current Status of the Agricultural Sector. Wellington, New Zealand: Ministry of Agriculture of New Zealand.

Nutrition Week. 1991. U.S. pesticide standards threaten world trade.Nutrition Week 21 (40): 6-7.

NZ. 1993. Agricultural Statistics 1993. Lincoln, New Zealand: Statistics New Zealand

Oerke, E.C., Dehne, H.W., Schonbeck, F. and Weber, A., 1994. Crop Production and Crop Protection: Estimated Losses in Major Food and Cash Crops. Amsterdam: Elsevier.

Pimentel, D., 1961. Animal population regulation by the genetic feedback mechanism. Am. Nat. 95: 65-79.

Pimentel, D., 1988. Herbivore population feeding pressure on plant host: feedback evolution and host conservation. Oikos 53: 289-302. 
Pimentel, D., 1993. Habitat factors in new pest invasions. Pp 165-181.In: Evolution of Insect Pests -Patterns of Variation, Kim, K.C. and McPheron, B.A. (Eds.) New York: John Wiley and Sons.

Pimentel, D., 1995. Protecting crops. Pp 49-66.In: The Literature of Crop Science. W.C. Olsen (Ed.) Ithaca, NY: Comell University Press.

Pimentel, D., 1997. Pest management in agriculture. Pp 1-12. In: Techniques for Reducing Pesticide Use: Economic and Environmental Benefits. D. Pimentel (Ed.) London: John Wiley.

Pimentel, D. and Greiner, A., 1997. Environmental and soci-economic costs of pesticide use. Pp 51-78. In: Techniques for Reducing Pesticide Use: Economic and Environmental Benefits. D. Pimentel (Ed.). Chichester, UK: John Wiley and Sons.

Pimentel, D., McLaughlin, L., Zepp, A., Kakitan, B., Kraus, T., Kleinman, P., Vancini, F., Roach, W.J., Graap, E., Keeton, W.S. and Selig, G., 1993. Environmental and economic effects of reducing pesticide use in agriculture. Agric. Ecosystems Environ. 46: 273-288.

Pimentel, D., Huang, X., Cardova, A., and Pimentel, M., 1997a. Impact of a growing populaltion on natural resources: the challenge for environmental management.In: Environmental Management in Practice: Analysis. Implementation, and Policy. L. Hens and D. Devuyst (Eds.). Brussels, Belgium.

Pimentel, D., Tort, M., D’Anna, L., Krawic, A., Berger, J., Rossman, J., Mugo, F., Doon, N., Shriberg, M., Howard, E., Lee, S. and Talbot, J., 1997b. Increasing disease incidence: environmental degradation and population growth. Manuscript.

Sailer, R.I., 1983. History of insect introductions. Pp 15-38. In: Exotic Plant Pests and North American Agriculture. C.L. Wilson and C.L. Graham (Eds.). New York: Academic Press.

Strong, D.R., McCoy, E.D. and Rey, J.D., 1977. Time and number of herbivore species: the pests of sugarcane. Ecology 58: 167-175

USBC. 1996. Statistical Abstract of the United States 1995. Vol. 200th ed. Washington, DC: U.S. Bureau of the Census, U.S. Government Printing Office.

WHO. 1992. Our Planet, Our Health: Report of the WHO Commission on Health and Environment. Geneva: World Health Organization.

WHO. 1995. Bridgring the Gaps. Geneva: World Health Organization.

Zilbemman, D.,1992. Environmental aspects of economic relations between nations. Am. J. Agric. Econ. 74 (5): 1143-1156. 